\title{
Kırsal peyzaj planlamasında kentli halkın rolü ve kimliğe ilişkin farkındalık düzeyi
}

\section{The role of urban folks in rural landscape planning and the level of awareness about identity}

\author{
Esra ÖZHANCI ${ }^{1}$, Hasan YILMAZ²
}

${ }^{1}$ Nevşehir Hacı Bektaşi Veli Üniversitesi, Mühendislik Mimarlık Fakültesi, Peyzaj Mimarlığı Bölümü, Nevşehir, Türkiye

${ }^{2}$ Atatürk Üniversitesi, Mimarlık ve Tasarım Fakültesi, Peyzaj Mimarlığı Bölümü, Erzurum, Türkiye

\section{Eser Bilgisi / Article Info}

Araştırma makalesi / Research article

DOI: 10.17474/artvinofd.270400

Sorumlu yazar / Corresponding author

Esra ÖZHANCl

e-mail: eozhanci@nevsehir.edu.tr

Geliş tarihi / Received

30.11.2016

Düzeltme tarihi / Received in revised form

27.01.2017

Elektronik erişim / Online available

27.02.2017

Anahtar kelimeler:

Kırsal peyzaj

Kentlilik bilinci

Kırsal planlama

\section{Keywords:}

Rural landscape

Urban consciousness

Rural planning

\begin{abstract}
Özet
Kırsal alanlar, temelde tarımsal faaliyetler ile çeşitli ekonomik faaliyetlerin de yer aldığı, ülkesel ölçekte fayda sağlayan peyzajlar olmasının yanında, kültürel desenin ve toplumsal dinamiklerin korunması açısından önem taşıyan çok yönlü mekanlardır. Şüphesiz, kentsel ve kırsal alanlarda zaman içerisinde meydana gelen sosyal ve fiziksel değişim ve dönüşüm, birbirinden ayrı düşünülmemelidir. Planlama ve koruma kararları alınırken, her iki toplumsal birliğin de fikrine başvurulmalı, kararların kalıcılığı bu fikir birliği ile sağlanmalıdır. Bu çalışmada; Erzurum kenti ve kırsal karakteri örneği ele alınmış, kentlinin kırsal alan planlaması açısından rolü irdelenmiş, kent halkının kırsal alan kimliği ile ilgili farkındalık düzeyleri ve bakış açıları ortaya konmuştur. Ankete katılanların \%69.8'inin köyünün ve \% 50.87 'sinin köyde evi olduğu belirtirken, ilin doğal ve kültürel dokusunun, bugün ki ve gelecekteki durumu ile alakadar olduklarını ve korumaya yönelik kentlilik bilincine sahip olduklarını ifade etmişlerdir. Ayrıca \%61.8'i, köyüne/sevdiği bir köye dönmeyi, ya da orda bir evi olmasını istediğini ifade etmiştir. Çalışmada yürütülen birebir anketler, istatistiki analize tabi tutulmuş, bu analizler doğrultusunda değerlendirmeler yapılmıştır.
\end{abstract}

\begin{abstract}
Rural areas are versatile spaces that include basic agricultural activities and a variety of economic activities, in addition to being benefit a national scale landscapes. They are also important for the protection the cultural patterns and the social dynamics. Undoubtedly, social and physical changes and transformation that occur over time in urban and rural areas should not be considered separate from each other. When planning and conservation decisions taken, it should be referred to the idea of both social cohesion, permanence of decisions should be provided with this consensus. In this study; example of the Erzurum city and rural character are discussed, in terms of rural planning the role of city folk was discussed, awareness and perspectives related to rural identity of city folk was revealed. While the majority of respondents $(69.8 \%)$ stated that they have a village and village house $(50.87 \%)$, they expressed that they concern with the situation of natural and cultural structure of the province and they have urban awareness intended to protect. In addition, $61.8 \%$ of respondents stated that they want to return to their village / favorite village, or have a house there. The one to one survey conducted in the study were subjected to statistical analysis, in accordance with this analysis the evaluation was made.
\end{abstract}

\section{GiRiş}

M.Ö. 430 yılında Perikles kentli olmaya ilişkin çağının ötesinde öngörülerde bulunmuştur; "İçimizde, evimiz ve kentimize duyduğumuz özeni birbirinden ayrılmaz duygular olarak taşırız. Kişiler ayrı çabalar içinde de olsalar, kent sorunları karşısında kimse umursamazlık edemez. Kent sorunlarına aldırmayan kişiye sessiz bir yurttaş değil, kötü bir yurttaş denir. Kentimizi ilgilendiren konulara bizler karar verir ya da bu konuda en doğruyu bizler düşünürüz. Çünkü eylemden önce girişilecek sözlü tartışmalar zararlı sonuç vermez, ama bu tür görüşmeler yapılmadan girişilen işler, olumsuz sonuçlar doğurabilir." (Çakılcıoğlu ve ark. 2003; Beyazlı ve Aydemir 2008). Toplum ve çevre arasındaki geçmişteki ve bugün ki ilişkilere tanıklık eden kültürel peyzajlar, insan ve doğa arasındaki etkileşimi de beraberinde getirmektedir (Rescia et al. 2008). Ekolojik dengenin giderek bozulduğu yeryüzü, insan faaliyetlerinin ve yaşamsal alanlarının doğa üzerinde kurduğu baskılardan fazlasıyla etkilenmektedir. Bu noktada kentli olma bilinci daha da önem kazanırken, kendisine sunulan olanakları sonuna kadar kullanma kararlıı̆ı̆ında olan insanoğlunun, bir takım farkındalıklara sahip olması gerekliliği ortaya çıkmaktadır. Ayrıca bu bilinç toplumsal güdünün de bir parçası, geleneksel yapının bozulmamışlığının bir işaretidir.

Bu bağlamda bir kenti kırsalından ayırmak doğru olmadığı gibi, planlama başarısızlıklarının da temelidir. Her kent, kent merkezi, banliyöleri ve kırsalı ile bir bütündür ve 
birinde yaşanan aksaklık diğerinde sonuçlarını göstermektedir. Bütün bu parçaların paydaşları, bu birlikteliği doğru anlamalı, aksiyonlar ve ortaya çıkardığı reaksiyonların bilincinde olmalıdır.

"Kentsel miras, mekân kalitesi ve kentsel tasarım" adlı raporda; kent kimliğini oluşturan doğal ve kültürel değerlerin bozulması kentlerimizdeki mekansal kalite, tasarım ve estetik değerlere ilişkin sorunlarından biri olarak görülmüştür (Anonim 2009).

Kırsal alanlarda da durum çok farklı olmamaktadır. Kentsel kullanımların kırsal alanlara sıçraması, turizm ve ikinci konut yapılaşmaları gibi nedenlerle kırsal alanların özgün kimliklerinde de yıpranmalar olmaktadır. Bu durumda kentlerin ve kırsal alanların yerel dokusunu güçlendirecek ve geçmişle gelecek arasında bir köprü kurarak, kimlik olgusunu koruyan, koruma-geliştirmeyenileme ve sürekliliğinin sağlanması amacına katkı sağlayacak planlamalara gereksinim vardır (Kiper 2013).

Beyazlı ve Aydemir (2008) ülkemizde uygulanan farklı ölçeklerdeki planlama çalışmalarında katılımcı yaklaşımın denenmesine karşın, beklenen hedeflere ulaşılamamasının nedenlerini şöyle sıralamıştır:

- Halk tarafından bu projelerin destek görmemesi ve anlaşılamaması,

- Katılımın ilkelerinin ve yöntemlerinin yasal mevzuatta belirlenmemiş olması ve katılımın yasal bir zorunluluk olmaması,

- Halkın yeterince bilinçlendirilmemesi (belki de halkın bilinçlendirilmesinin bir tehdit olarak görülmesi)

- Katılımın uzun vadede alınabilecek sonuçlarının, kısa vadede alınmak istenmesi,

- Yerel düzeydeki çalışmalarla ve küçük projelerle, halkta siyasal etkinlik duygusunun yeterli derecede geliştirilememesi,

- Yerel yönetimlerce hızlı, sorunsuz ve az sesli bir planlama sürecinin istenmesi,

- Başarısız örnekler

Köy, en basit ifade ile insanların bir arada yaşadığı en küçük yerleşim birimidir. Büyük ölçüde gelenekselliğin hâkim olduğu köylerin ortaya çıkışı dünyada olduğu gibi ülkemizde de köklü geçmişe sahiptir (Eldem 2015).
Kanuna(442 Sayılı Köy Kanunu) göre; nüfusu 2000'in altında olan bu yerleşimler, tüzel kişiliğe sahip en küçük yerleşim birimleridir.

Gallent et al. (2008)'e göre; kırsal alanları ve kırsal yaşamı temsil eden kırsallık, Sosyal içerik, Politik-ekonomik çerçeve, işlevsel çerçeve şeklinde üç farklı kavramsal çerçevede değerlendirilmelidir.

Kırsal yerleşimler işlevlerinin birlikte yapıldığı ya da birinin diğerine göre ön plana çıktığı genel, tarım ve hayvancılık olarak nüfusun az olduğu ve halen dünya nüfusunun yarısından çoğunu barındıran yerleşimlerdir. Kırsal yerleşim alanlarının yer seçimi ve gelişiminde etkili olan faktörler doğal ve kültürel faktörler olup en önemli etken doğal faktörlerdir. Fakat bu alanların nasıl kullanıldığı orada yaşayan insanların tarihi, sosyolojik ve ekonomik yapıları ile gelişmişlik düzeylerine bağlıdır. Dolayısıyla yerleşim yerlerinin gelişmeleri, şekillenmeleri ve çeşitli tiplere ayrılmasında kültürel faktörler de etkili olmaktadır. Doğal ve kültürel faktörler çok yerde birlikte etkili olmakta, bazen biri bazen de diğeri öne çıkmaktadır (Şahin 1998; Yılmaz ve Atik 2006).

Türkiye için nüfus yoğunluğun nüfus hareketi ile ilişkisi aşağıdaki gibi ifade edilebilir (Güreşçi 2010):

- 1950'lerde kentsel nüfus oranı kırsal nüfus oranından daha fazladır. Nüfus çok yoğundan az yoğuna doğru hareket etmiştir. Bu durumda itici faktörler kırsalda, çekici faktörler ise kentlerde ön plana çıkmıştır.

- 1950'lerden sonra kırsaldan kentlere doğru nüfus hareketi devam etmiş ve nüfus yoğunluğu neredeyse dengelenmiştir. Kentlerin çekiciliği artarak devam etmiş ve kırsalın iticiliğinden daha fazla kendisini göstermiştir.

- 2000'li yıllara doğru; kırsaldan kentlere olan nüfus hareketi devam etmekte sonuçta kentsel nüfus oranı kırsaldan daha fazladır. Bu durumda, kentsel bölgelerde çekiciliğin yanı sıra iticilik faktörü de belirginleşmeye başlamıştır. Tekrar yoğun nüfustan az yoğun nüfusa doğru bir hareketlenme başlamıştır. Bu ise kentten köye göçlerin belirginleşmeye başlaması ile sonuçlanmıştır.

Görülmektedir ki yoğunlaşan kentlerin, cazibesini kaybetmesi ile kırsal alanlara ilgi artmıştır. Insan hareketi tersi yöne doğru meyil etmeye başlamıştır. Kentsel 
alanları bu yoruculuklardan arındırmak, kırsal alanların ise yaşanabilirliklerini artırmak gereği ortaya çıkmaktadır.

Ülkesel, bölgesel ve yöresel ölçekte doğal ve kültürel pek çok değerin farkı oluşu, planlamaya da yansıtılmalıdır. Zaten bir kenti diğer kentlerden ayıran en önemli özellik, o kentin kendine ait bir karaktere sahip olmasıdır. Bu karakter, zamanla gelişir ve o kentin etiketi haline gelir (llgar 2008).

$\mathrm{Bu}$ çalışmanın amacl; Erzurum kentinde yaşayan sakinlerin, yaşadıkları kente bakış açılarını belirlerken, katılımcı planlama düzleminde halkın etkinlik düzeyi ve potansiyelini ortaya koymaktır. Bu bağlamda, kentlinin kırsalla ilişkilerini ortaya koymak ve elde edilen sonuçların planlama açısından getirilerini analiz etmektir.

\section{MATERYAL ve YÖNTEM}

\section{Materyal}

Çalışmanın materyalini Çoruh, Fırat ve Aras Havzalarının başlangıç alanlarında bulunan Erzurum ili oluşturmaktadır. il kuzeyde Rize'nin ikizdere ve Çamlıhemşin, Artvin'in Yusufeli ve Ardanuç, batıda Bayburt'un merkez ilçe ve Aydıntepe, Erzincan'ın Tercan ve Otlukbeli, güneyde Bingöl'ün Yedisu ve Karlıova, Muş'un Varto, Bulanık ve doğuda Kars'ın Selim ve Sarıkamış Ağrı́nın Eleşkirt ve Tutak, Ardahan'ın Göle ilçeleri ile çevrilidir (Şekil 1).

Erzurum ilinin, iki coğrafi bölgede toprakları bulunmakta olup, arazi büyüklüğü, yaklaşık 2.506.600 ha kadar tutar. Ülke topraklarının \%3.2 sini kaplayan Erzurum'un kuzeyden İspir, Narman, Oltu, Olur, Pazaryolu, Tortum ve Uzundere ilçelerinin toprakları, Karadeniz Bölgesinin Doğu Karadeniz sınırları içinde kalmaktadır. Ancak bu kesim, il topraklarının yaklaşık \%30'luk bir payını oluşturur. Geriye kalan \%70 gibi önemli bir pay, Doğu Anadolu Bölgesi dahilinde yer alır. İl, arazi büyüklüğü bakımından, sırayla Konya, Sivas ve Ankara illerinden sonra, Türkiye'nin 4. büyük ili konumundadır (Anonim 1998; Irmak 2008). Bu karma coğrafi yapı, ilin kırsal alanlarında çeşitliliğe neden olmuş, peyzaj karakterini çeşitlendirmiştir.

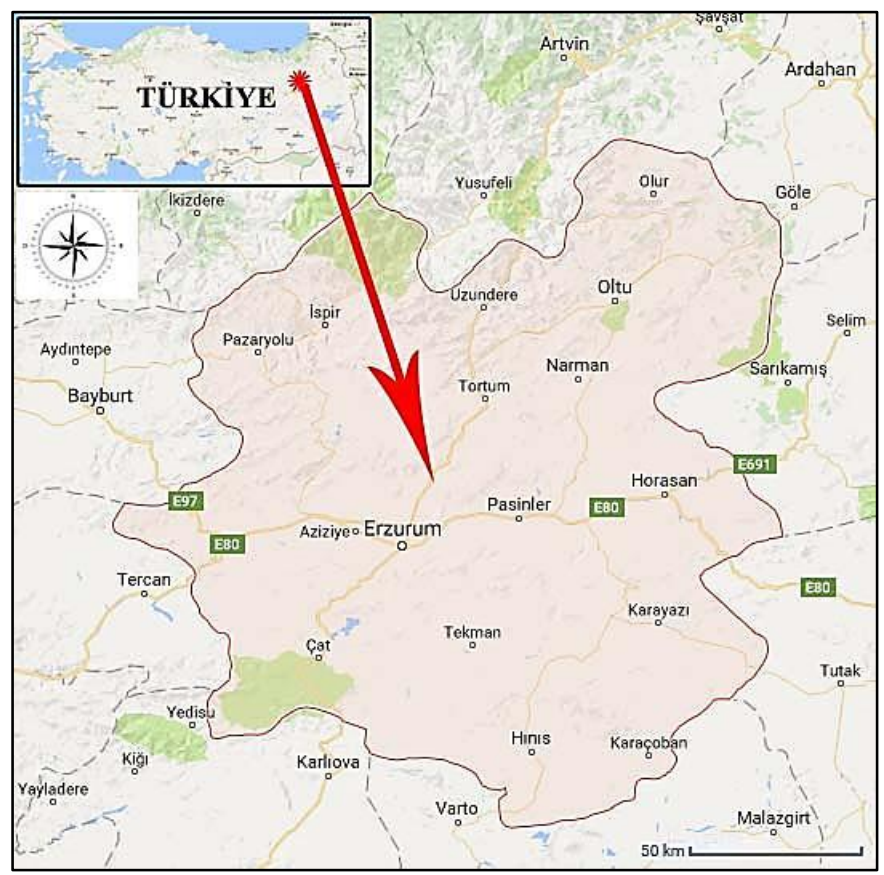

Şekil 1. Araştırma alanının konumu

OECD, kırsal alanlar için $A B$ metinlerinde de kullanılan bir tanım geliştirmiştir. Buna göre kırsal alanlar nüfus yoğunluğunun $\mathrm{km}^{2}$ başına 150 kişinin altında olduğu topluluklardır. Bu tanım ışığında bölgeler üç gruba ayrılmış, nüfusunun $\% 50$ 'den fazlası kırsal topluluklarda yaşayanlar kırsallığı baskın bölgeler, \%15-50 arası kırsal topluluklarda yaşayanlar önemli ölçüde kırsal bölgeler, nüfusun \%15'in den azı kırsal topluluklarda yaşadığı bölgeler ise kentselliği baskın bölgeler olarak sınıflandırılmıştır (Anonim 2012). Erzurum ilinin 780.847 'lik toplam nüfusunun, \%35.29'u kırsal alanlarda yaşamaktadır (Anonim 2014). OECD'nin tanımı ışı̆ıında Erzurum ili, önemli ölçüde kırsal bölgeler sınıfındadır (Tablo 1).

Tablo 1. 2011 yılı TUik verileri ile Erzurum ili nüfus göstergeleri

\begin{tabular}{|c|c|c|c|c|c|}
\hline $\begin{array}{l}\text { Toplam } \\
\text { nüfus }\end{array}$ & $\begin{array}{l}\text { il ve ilçe } \\
\text { merkezleri } \\
\text { nüfusu }\end{array}$ & $\begin{array}{l}\text { Belde ve } \\
\text { köyler } \\
\text { nüfusu }\end{array}$ & $\begin{array}{l}\text { İl ve ilçe merkezleri nüfusunun } \\
\text { toplam nüfus içindeki oranı (\%) }\end{array}$ & $\begin{array}{l}\text { Belde ve köyler nüfusunun toplam } \\
\text { nüfus içindeki oranı (\%) }\end{array}$ & $\begin{array}{l}\text { Yıllık nüfus artış } \\
\text { hızı (binde) }\end{array}$ \\
\hline 780847 & 505254 & 275593 & 64.71 & 35.29 & 15.18 \\
\hline
\end{tabular}




\section{Yöntem}

Bu çalışma Erzurum kenti genelinde, binde bir örnekleme (kent nüfusu 412.326 kişi) alınarak uygulanan 384 anketin geri dönüşleri sonucunda, toplam 325 katılımcı ile birebir görüşme yöntemi kullanılarak yapılan bir anket çalışmasının sonuçlarını yansıtmaktadır.

Üç bölümden oluşan anketin ilk bölümünde, katılımcıların kişisel özellikleri belirlenmiştir. İkinci bölümde(A grubu sorular), katılımcıların köy hayatı ile aşinalıklarına yönelik sorular yer almıştır. Anket kapsamında kent halkının kırsal alanlarla ilgili farkındalık düzeyleri ve bakış açıları, yaşadıkları kente yaşanabilirlik açısından yaklaşımları ortaya konmaya çalışımıştır. Bu amaçla, üçüncü bölümde (B grubu sorular) katılımcılara konuya bakış açılarını ortaya koymak amacıyla bir dizi soru yöneltilmiştir. Değerlendirilme ölçeği, Likert (1932)'in beşli değerlendirme ölçeği; "kesinlikle katılıyorum, katılıyorum, fikrim yok, katılmıyorum, kesinlikle katılmıyorum" şeklinde oluşturulmuştur (Bayat 2014). Çalışmada, analizlerde 'SPSS Statistics 22' istatistik paket programı kullanılmış, nonparametrik testler uygulanmıştır. Sorulara verilen yanıtlar yüzde ve frekans dağılım tabloları şeklinde verilmiştir. Değişkenler arası ilişki Pearson Korelasyon testi ile belirlenmiştir.

\section{BULGULAR}

Katılımcıların \%55.4'ü erkek iken, \%75.7'si kent merkezinde doğmuştur. \%46.2'si kamuda çalışmaktadır (Tablo 2).

Köy hayatına aşinalıkların değerlendirildiği bölümde (A grubu); ankete katılanların \%69.8'inin köyünün ve \%50.87'sinin köyde evi olduğu, \%12.18 inin köyüne hiç gitmediği saptanmıştır (Tablo 3).

Tablo 2. Katılımcıların kişisel özellikleri

\begin{tabular}{|c|c|c|c|}
\hline Demografik Faktörler & Katılımcılar & Toplam(Frekans) & Toplam(\%) \\
\hline \multirow{2}{*}{ Cinsiyet } & Erkek & 180 & 55.4 \\
\hline & Kadın & 154 & 44.6 \\
\hline \multirow{4}{*}{ Yaş } & $18-24$ & 86 & 26.5 \\
\hline & $25-34$ & 104 & 32.0 \\
\hline & $35-44$ & 98 & 30.2 \\
\hline & $45-54$ & 37 & 11.4 \\
\hline \multirow{4}{*}{ Meslek } & İşsiz & 32 & 9.8 \\
\hline & Kamuda çalışan & 150 & 46.2 \\
\hline & Özel sektörde çalışan & 85 & 26.2 \\
\hline & Öğrenci & 58 & 17.8 \\
\hline \multirow{2}{*}{ Medeni durum } & Evli & 168 & 51.7 \\
\hline & Bekar & 157 & 48.3 \\
\hline \multirow{4}{*}{ Öğrenim } & İlköğretim & 23 & 7.1 \\
\hline & Lise & 122 & 37.5 \\
\hline & Üniversite & 145 & 44.6 \\
\hline & Yüksek lisans/doktora & 35 & 10.8 \\
\hline \multirow{4}{*}{ Gelir durumu } & 850-1500 TL arası & 56 & 17.2 \\
\hline & $1501-3000$ TL arası & 119 & 36.6 \\
\hline & $3001-5000$ TL arası & 84 & 25.8 \\
\hline & 5001 TL ve üzeri & 66 & 20.3 \\
\hline \multirow[b]{2}{*}{ Doğum yeri } & Kent merkezi & 246 & 75.7 \\
\hline & Köy & 79 & 24.3 \\
\hline
\end{tabular}


Tablo 3. Katılımcıların köy hayatı ile aşinalıklarına yönelik cevapların dağılımı

\begin{tabular}{lll}
\hline Soru & Cevap & Oran (\%) \\
\hline \multirow{2}{*}{ Köyünüz var mı? } & Evet & $\mathbf{6 9 . 8}$ \\
& Hayır & 30.2 \\
\hline & Haftada bir & 10.86 \\
& Ayda bir & 16.96 \\
\multirow{2}{*}{ Ne sıklıkla gidersiniz? } & Yılda bir & 24.35 \\
& Yılda birkaç kez & $\mathbf{3 5 . 6 5}$ \\
& Gitmem & 12.18 \\
\hline \multirow{2}{*}{ Köyde eviniz var mı? } & Evet & $\mathbf{5 0 . 8 7}$ \\
& Hayır & 49.13 \\
\hline
\end{tabular}

Katılımcılara yaşadıkları kente yaklaşımlarına yönelik 15 adet soru yöneltilmiştir. Ankete katılanların \%76.0'sı, Erzurum kentini yaşanabilir bir kent olarak değerlendirmiştir. Katılımcıların \%62.5'i kentte yaşamanın yorucu olduğunu belirtmiştir. Ayrıca katılımcılara göre; Erzurum kentinde yaşayanlar geleneklerini yaşadıkları alanlara yansıtmaktadır (\%56.3) (Tablo 4).

Tablo 4. Kentsel yaşama yaklaşım durumları dağılımı

\begin{tabular}{lll}
\hline Soru & Cevap & Oran (\%) \\
& kesinlikle katılıyorum & $\mathbf{2 6 . 5}$ \\
(B1) Erzurum kentini & katılıyorum & $\mathbf{4 9 . 5}$ \\
"yaşanabilir bir kent & fikrim yok & 7.1 \\
olarak" & katılmıyorum & 11.1 \\
değerlendiriyorum & kesinlikle katılmıyorum & 5.8 \\
& Toplam & 100.0 \\
\hline & kesinlikle katılıyorum & $\mathbf{2 7 . 7}$ \\
(B2) Kentte yaşamak & katılıyorum & $\mathbf{3 4 . 8}$ \\
zaman zaman beni çok & fikrim yok & 4.0 \\
yoruyor ve kırsal & katılmıyorum & 21.2 \\
alanlarda yaşıyor olmayı & kesinlikle katılmıyorum & 12.3 \\
istiyorum. & Toplam & 100.0 \\
\hline (B3) Bence Erzurum'da & kesinlikle katılıyorum & $\mathbf{2 1 . 8}$ \\
kentte yaşayanlar tarihi & katılıyorum & $\mathbf{3 4 . 5}$ \\
ve kültürel geleneklerini & fikrim yok & 8.6 \\
devam ettirmekte, & katılmıyorum & 22.8 \\
yaşadıkları kentsel & kesinlikle katılmıyorum & 12.3 \\
alanlara yansıtmaktadır & & \\
\hline
\end{tabular}

Tablo 5'de katılımcıların doğal ve kültürel değerlere duyarlıık durumları dağılımı yer almaktadır. Katılımcılar büyük oranda, ilin doğal ve kültürel değerlerinin yeterince korunamadığını ve tanıtılamadığını düşünmektedir. Ayrıca kişisel olarak ilin doğal ve kültürel dokusunun, bugün ki ve gelecekteki durumu ile ilgili olduklarını ve korumaya yönelik kentlilik bilincine sahip olduklarını ifade etmişlerdir.
Tablo 5. Doğal ve kültürel değerlere duyarlılık durumları dağılımı

\begin{tabular}{lll}
\hline Soru & Cevap & Oran \\
& & (\%) \\
& kesinlikle katılıyorum & 7.1 \\
& katılırum & 26.5 \\
(B4)Erzurum'un doğal ve & fikrim yok & 9.5 \\
kültürel değerleri yeterince & katılmıyorum & $\mathbf{3 7 . 8}$ \\
korunabilmektedir. & kesinlikle & 19.1 \\
& katılmıyorum & \\
& Toplam & 100.0 \\
\hline & kesinlikle katılıyorum & 5.8 \\
& katılıyorum & 22.2 \\
(B5)Erzurum'un doğal ve & fikrim yok & 8.3 \\
kültürel değerleri yeterince & katılmıyorum & 39.7 \\
tanıtılabilmektedir. & kesinlikle & 24.0 \\
& katılmıyorum & \\
& Toplam & 100.0 \\
\hline & kesinlikle katılıyorum & 24.0 \\
(B6)Erzurum'un doğal ve & katılıyorum & 47.7 \\
kültürel dokusunun, bugün ki & fikrim yok & 10.2 \\
ve gelecekteki durumu beni & katılmıyorum & 12.6 \\
düşündürür. & kesinlikle & 5.5 \\
& katılmıyorum & \\
\hline & Toplam & 100.0 \\
\hline (B7)Kentin tarihi, kültürel ve & kesinlikle katılıyorum & 21.5 \\
doğal mirasının korunmasına & katılıyorum & 39.7 \\
yönelik kentlilik bilincine sahip & fikrim yok & 11.4 \\
olduğumu düşünüyorum. & kesinlikle & 18.5 \\
& katılmıyorum & 8.9 \\
\hline & Toplam & 100.0 \\
\hline & & \\
& &
\end{tabular}

Katılımcıların büyük çoğunluğu, köylerde yaşayanların geleneklerini devam ettirdiğini ve yaşadıkları kırsal alanlara yansıttığını (\%65.2), Erzurum'un köylerinin gezilip görülmeye değer olduğunu belirtmiştir. Ayrıca katılımcılara göre; Erzurum ili kendine özgü bir kırsal dokuya sahiptir ve Erzurum ili bütününde kırsal yapı çok çeşitlidir (\%62.1) (Tablo 6).

Katılımcılar kendi köyleri dışında özellikle görmeye gittikleri köyler olduğunu belirtmişlerdir. $\% 61.8^{\prime} \mathrm{i}$, köyüne/sevdiği bir köye dönmeyi, ya da orda bir evi olmasını istediğini ifade ederken, her kentli insanın, yılın bir bölümünü köyde değerlendirmesi gerektiğini belirtmişlerdir (Tablo 6). 
Tablo 6. Kırsal alan kavramı ve Erzurum'un kırsal yapısına ilişkin dağıım

\begin{tabular}{|c|c|c|}
\hline Soru & Cevap & $\begin{array}{l}\text { Oran } \\
\text { (\%) }\end{array}$ \\
\hline \multirow{6}{*}{$\begin{array}{l}\text { (B8) Bence Erzurum'da } \\
\text { köylerde yaşayanlar tarihi } \\
\text { ve kültürel geleneklerini } \\
\text { devam ettirmekte, } \\
\text { yaşadıkları kırsal alanlara } \\
\text { yansıtmaktadır. }\end{array}$} & kesinlikle katılıyorum & 21.8 \\
\hline & katılıyorum & 43.4 \\
\hline & fikrim yok & 11.7 \\
\hline & katılmıyorum & 14.2 \\
\hline & kesinlikle katılmıyorum & 8.9 \\
\hline & Toplam & 100.0 \\
\hline \multirow{6}{*}{$\begin{array}{l}\text { (B9)Erzurum'un köyleri } \\
\text { gezilip görülmeye değer } \\
\text { güzelliktedir. }\end{array}$} & kesinlikle katılıyorum & 25.8 \\
\hline & katılıyorum & 39.1 \\
\hline & fikrim yok & 12.3 \\
\hline & katılmıyorum & 16.9 \\
\hline & kesinlikle katılmıyorum & 5.8 \\
\hline & Toplam & 100.0 \\
\hline \multirow{6}{*}{$\begin{array}{l}\text { (B10)Bence Erzurum, } \\
\text { kendine özgü bir kırsal } \\
\text { dokuya sahiptir. }\end{array}$} & kesinlikle katılıyorum & 28.3 \\
\hline & katılıyorum & 47.7 \\
\hline & fikrim yok & 10.8 \\
\hline & katılmıyorum & 9.2 \\
\hline & kesinlikle katılmıyorum & 4,0 \\
\hline & Toplam & 100.0 \\
\hline \multirow{6}{*}{$\begin{array}{l}\text { (B11)Bence Erzurum ili } \\
\text { bütününde kırsal yapı çok } \\
\text { çeşitlidir. }\end{array}$} & kesinlikle katılıyorum & 25.5 \\
\hline & katılıyorum & 36.6 \\
\hline & fikrim yok & 11.7 \\
\hline & katılmıyorum & 20.9 \\
\hline & kesinlikle katılmıyorum & 5.2 \\
\hline & Toplam & 100.0 \\
\hline \multirow{6}{*}{$\begin{array}{l}\text { (B12)Bence bir ilin; kentsel } \\
\text { ve kırsal alanlarını bir } \\
\text { bütün olarak } \\
\text { değerlendirmek gerekir. }\end{array}$} & kesinlikle katılıyorum & 27.7 \\
\hline & katılıyorum & 34.8 \\
\hline & fikrim yok & 4.0 \\
\hline & katılmıyorum & 21.2 \\
\hline & kesinlikle katılmıyorum & 12.3 \\
\hline & Toplam & 100.0 \\
\hline \multirow{6}{*}{$\begin{array}{l}\text { (B13)Erzurum'da, benim } \\
\text { köyüm olmadığı halde, } \\
\text { özellikle gezip görmeye } \\
\text { gittiğim köyler var. }\end{array}$} & kesinlikle katılıyorum & 18.5 \\
\hline & katılıyorum & 36.6 \\
\hline & fikrim yok & 8.9 \\
\hline & katılmıyorum & 23.4 \\
\hline & kesinlikle katılmıyorum & 12.6 \\
\hline & Toplam & 100.0 \\
\hline \multirow{6}{*}{$\begin{array}{l}\text { (B14)Ekonomik } \\
\text { olanaklarım uygun } \\
\text { olduğunda } \\
\text { köyüme/sevdiğim bir köye } \\
\text { dönmeyi, ya da orda bir } \\
\text { evim olmasını isterim. }\end{array}$} & kesinlikle katılıyorum & 32.9 \\
\hline & katılıyorum & 28.9 \\
\hline & fikrim yok & 12.3 \\
\hline & katılmıyorum & 13.2 \\
\hline & kesinlikle katılmıyorum & 12.6 \\
\hline & Toplam & 100.0 \\
\hline \multirow{6}{*}{$\begin{array}{l}\text { (B15)Her kentli insan, } \\
\text { kendi köyü olsun olmasın, } \\
\text { yılın bir bölümünü köyde } \\
\text { değerlendirmelidir. }\end{array}$} & kesinlikle katılıyorum & 39.4 \\
\hline & katılıyorum & 38.5 \\
\hline & fikrim yok & 7.1 \\
\hline & katılmıyorum & 8.3 \\
\hline & kesinlikle katılmıyorum & 6.8 \\
\hline & Toplam & 100.0 \\
\hline
\end{tabular}

Tablo 7,8 ve 9'da, üçüncü bölümde yer alan (B grubu), sorulara verilen yanıtlar arası ilişkiyi gösteren Korelasyon Testi sonuçları verilmiştir. Soru grupları kendi içerisinde ilişkilendirilmiştir. Kentsel yaşama yaklaşım durumları sorularına verilen yanıtlar arası ilişki Tablo 7'de, doğal ve kültürel değerlere duyarlılık durumlarına ilişkin sorulara verilen yanıtlar arası ilişki Tablo 8'de, kırsal alan kavramı ve Erzurum'un kırsal yapısına ilişkin sorulara verilen yanıtlar arası ilişki Tablo 9'da verilmiştir.

Görülmektedir ki; yanıtların büyük çoğunluğu istatistiki olarak birbiri ile ilişkilidir. Örneğin; Kentsel yaşama yaklaşım durumları sorularında, "Bence Erzurum'da kentte yaşayanlar tarihi ve kültürel geleneklerini devam ettirmekte, yaşadıkları kentsel alanlara yansıtmaktadır" ifadesi ile "Erzurum kentini yaşanabilir bir kent olarak değerlendiriyorum" ifadesi ( $p: 0,000, p<0,01)$ ve "Kentte yaşamak zaman zaman beni çok yoruyor ve kırsal alanlarda yaşıyor olmayı istiyorum." ifadesi ( $p: 0,006, p<$ $0,01)$ arasındaki ilişki istatistiki açıdan çok önemlidir. Kent sakinleri kentte yaşayanların kültürlerine bağlı olduklarını düşünmektedir ve aynı zamanda kenti yaşanabilir bulmaktadır. Ancak zaman zaman kentten uzak kırsalda yaşamayı da istemektedir. Yanıtlar birbirine paralellik göstermektedir.

Tablo 7. Kentsel yaşama yaklaşım durumları sorularına verilen yanıtlar arası ilişkiyi gösteren Pearson Korelasyon testi

\begin{tabular}{lll}
\hline & B1 & B2 \\
\hline B1 & \\
B2 & .054 & \\
B3 & $.217^{* *}$ & $.152^{* *}$ \\
\hline$* * p<0,01(\% 1$ seviyesinde önemli) &
\end{tabular}

Tablo 8. Doğal ve kültürel değerlere duyarlılık durumları sorularına verilen yanıtlar arası ilişkiyi gösteren Pearson Korelasyon testi

\begin{tabular}{clll}
\hline & B4 & B5 & B6 \\
\hline B5 & $.436^{* *}$ & & \\
B6 & -.050 & .042 & $.148^{* *}$ \\
B7 & $.234^{* *}$ & $.140^{*}$ & \\
\hline${ }^{*} p<0.05(\% 5$ seviyesinde önemli) & \\
$* * p<0,01(\% 1$ seviyesinde önemli) &
\end{tabular}


Tablo 9. Kırsal alan kavramı ve Erzurum'un kırsal yapısına ilişkin sorulara verilen yanıtlar arası ilişkiyi gösteren Pearson Korelasyon testi

\begin{tabular}{|c|c|c|c|c|c|c|c|}
\hline & B8 & B9 & B10 & B11 & B12 & B13 & B14 \\
\hline B9 & $0.383^{*}$ & & & & & & \\
\hline B10 & $0.203^{*}$ & $0.374 * *$ & & & & & \\
\hline B11 & $0.289 *$ & $0.416^{* *}$ & $0.505^{* *}$ & & & & \\
\hline B12 & $0.118^{*}$ & $0.112^{*}$ & $0.113^{*}$ & $0.130^{*}$ & & & \\
\hline B13 & $0.352 *$ & $0.413^{* *}$ & $0.148 * *$ & $0.217^{* *}$ & 0.084 & & \\
\hline B14 & $0.228 *$ & $0.261^{* *}$ & $0.209 * *$ & $0.202 * *$ & $0.120 *$ & $0.282 * *$ & \\
\hline B15 & $0.250 *$ & $0.353^{* *}$ & $0.270 * *$ & $0.333^{* *}$ & $0.309 * *$ & $0.266^{* *}$ & $0.477^{* *}$ \\
\hline
\end{tabular}

${ }^{*} p<0.05$ (\%5 seviyesinde önemli)

$* * p<0.01$ (\%1 seviyesinde önemli)

Doğal ve kültürel değerlere duyarlılık durumları sorularında ise; Erzurum'un doğal ve kültürel değerlerinin yeterince tanıtılmadığını düşünenler, aynı zamanda yeterince korunmadığı düşüncesini de taşımaktadır ( $p: 0,000, \quad p<0,01)$. “Erzurum'un doğal ve kültürel dokusunun, bugün ki ve gelecekteki durumu beni düşündürür." ifadesi ile "Kentin tarihi, kültürel ve doğal mirasının korunmasına yönelik kentlilik bilincine sahip olduğumu düşünüyorum." ifadesi arasındaki ilişkiler de istatistiki olarak çok önemlidir ( $p: 0,007, p<0,01)$, yanıtlar paralellik göstermiştir.

Kırsal alan kavramı ve Erzurum'un kırsal yapısına ilişkin sorularda, yanıtların tümü birbiri ile istatistiki açıdan ilişkilidir ve paralellik göstermektedir. Örneğin; Erzurum ili bütününde kırsal yapı çok çeşitli olduğunu düşünen katılımcılar, aynı zamanda Erzurum'un kendine özgü bir kırsal dokuya sahip olduğunu düşünmektedir ( $p: 0,000, p<$ 0,01).

\section{SONUÇ}

Son dönemlerde alternatif turizm (ekoturizm, agroturizm vb.) faaliyetlerine yönelik çalışmalar, kırsal alanlara ilgi çekilmesi sağlanmıştır. Kırsal alanlar çoğunlukla turizm faaliyetleri ekseninde ele alınmıştır. Turist-yerli halkın görüş ve düşüncelerine başvurulmuş, kentlinin kırsala yaklaşımı ele alınmamıştır. Paydaşlar açısından bakıldığında, meselenin farklı yönleriyle değerlendirilmesi gerekliliği ortaya çıkmaktadır. Nitekim kent halkı ne kadar olayın dışında da görünse, kırsal alan faaliyetlerinden direkt ve indirekt biçimde etkilenmektedir. Yapılan çalışma, farklı bir bakış açısı sunma amacıyla gerçekleştirilmiş, bundan sonraki stratejik çalışmalar için ipuçları sunmak hedeflenmiştir.
Üzerinde çokça durulan çevresel farkındalık, modernleşen hayatla birlikte hassasiyeti artmış bir kavram haline gelmiştir. Teknolojinin ve günlük hayatın içinde hapsolan insan, hızlı hayatın gereklerini yaşadığı kentte ararken, kentten uzak kırsal alanlarda ise doğasında var olan ihtiyaçlarını aramaktadır. Şüphesiz insan doğanın bir parçasıdır ve doğa deneyiminin psikofiziksel faydaları ortaya çıkmaktadır.

Türkiye'de üretilen kırsal kalkınma politikaları Avrupa'da olduğu gibi uzun süre tarımsal kalkınma odaklı olmuştur. Ortaya konulan hedefler daha çok kent-kır arasındaki dengesizliklerin giderilmesi amacıyla gerçekleştirilen hizmet götürme faaliyetleriyle sınırlı kalmıştır. Türkiye'de kalkınma planlarının geneline ve işleyiş sürecine bakılacak olursa, kırsal planlama kararlarının yerel değerleri göze almayan masa başında alınan kararlar ile şekillenen merkeziyetçi yaklaşımlar çerçevesinde geliştirilmektedir (Erdem 2012). Bu açıdan ele alındığında, yerel ölçekli çalışmaların ve yerel halkın katılımının kırsal alan stratejileri açısından gerekli ve önemli olduğu görülmektedir.

Kırsal peyzajlar çok sayıda unsurun bir araya gelmesinden oluşan yaşam alanlarıdır. Ancak köy/çiftlik evi ve tarımsal alandan oluşan peyzaj temel oluşturmakta, yaklaşımlar bu algının çevresinde şekillenmektedir. Zaizhi (2000)'e göre; kırsal peyzajlar boyut, şekil ve düzeni değişen, doğal ve insan yönetimi alan kullanımlarının mozaiğidir.

Çalışma amacı ve elde edilen sonuçlar incelendiğinde; kent halkı duyarlılıkları, beklentileri ve sahip oldukları potansiyelleri ile kırsal alandan kopuk olmayan, aksine farkındalığı yüksek bir profil çizmiştir. Bu da çalışmanın elde etmeyi hedeflediği bir sonuca götürmüş, kent halkının katılımcı planlamada alacağı değerli rolü 
desteklemiştir. Erzurum kentlisi, köyü (\%69.8) ve köyde eviyle bir yaşam şeklini benimseme tipolojisinde bir kimlik sergilemektedir. Kırsal kimliğe hiç de uzak değildir. Yaşadıkları kenti dezavantajları ile birlikte yaşanılabilir olarak değerlendirirken (\%76.0), zaman zaman kırsal alan deneyimi intiyacı duymaktadırlar. Doğal ve kültürel mirasında yeterince korunup, tanıtılamadığını düşünmekte olan kent halkı, bu noktada kendini paydaş ve sorumlu hissetmeli, bu alanda daha aktif katılım göstermelidir.

Erzurum ili, özgün konumu, hareketli topoğrafik yapı ve buna bağlı çeşitliliği ile kırsal alan potansiyeli açısından doğru değerlendirilmeli, sahip olduğu değerlerin farkına varılmalıdır. Bu noktada, farkındalığın yerel halk düzeyinde artırılması, halkın kendi çevresel ve kültürel değerlerine yakın olması ve sahip çıkması ile mümkün olacaktır. Kentlinin kırsalıyla temasını artıracak çalışmalar yapılmalı, ortaya konan projelerde kentli-köylü ortaklığı vurgulanmalıdır. Kentleşme yönü ve kentleşme tiplemesinde de kırsal dokunun rolü dikkate alınmalıdır.

Tarımsal üretim alanların korunmasına yönelik tedbirler alınmalı, ayrıca hobi bahçeleri, agro turizm faaliyetleri ile yakın ve özgün köy ve kırsal alanlara seyahat planlaması ortaya konmalıdır. Özellikle mevsimsel değişim yaşandığı dönemlerde artan cazibe potansiyeli, agro turizm faaliyetleri ile değerlendirilmelidir.

\section{KAYNAKLAR}

Anonim (1998) Erzurum 98, "Cumhuriyetin 75. Yılında Erzurum" Yılı̆̆ı, Erzurum Valiliği Yayını, Önder Matbaası, Erzurum

Anonim (2014). Türkiye İstatistik Kurumu Bölgesel Göstergeleri, http://tuikapp.tuik.gov.tr/Gosterge/?locale=tr

Anonim (2009) Kentges, Kentleşme şûrası kentsel miras, mekân kalitesi ve kentsel tasarım komisyonu raporu, Bayındırlık ve İskân Bakanlığı, Ankara
Anonim (2012) Avrupa Birliği Kırsal Kalkınma Politikaları ve Değişim Eğilimleri. Ziraat mühendisleri odası, www.zmo.org.tr/resimler/ekler/

Bayat B (2014) Uygulamalı Sosyal Bilim Araştırmalarında Ölçme, Ölçekler Ve "Likert" Ölçek Kurma Tekniği, Gazi Üniversitesi İktisadi ve İdari Bilimler Fakültesi Dergisi 16/3, 1-24

Beyazlı DŞ, Aydemir Ş (2008) Kentlilik Bilinci ve Mekân: Trabzon Kenti Örneği, Planlama,2008/3

Çakılcıoğlu N, Tekkökoğlu T, Faruk Ö, Çakılcıoğlu M (2003) Nasıl Bir Șehircilik?, [http://www.kentli.org/makale/ nasil.htm]

Eldem H (2015) Yerel Yönetimler Reformunun Bir Parçası Olarak Köy Kanunu Tasarı Taslağı. Optimum Ekonomi ve Yönetim Bilimleri Dergisi, 2(1), 39-61

Erdem M (2012) Kırsal Yerleşim Peyzaj Kimlik Özelliklerinin Tespiti, Korunması Ve Geliştirilmesine Yönelik Değerlendirme Matisi Önerisi, İstanbul Teknik Üniversitesi Fen Bilimleri Enstitüsü, Doktora Tezi, İstanbul

Gallent, N, Juntti, M, Kidd, S, Shaw, D (2008) Introduction to Rural Planning, Routledge, Taylor and Francis Group.

Güreşci E (2010) Türkiye'de Kentten - Köye Göç Olgusu, Doğuş Üniversitesi Dergisi, 11 (1), 77-86

Ilgar E (2008) Kent kimliği ve kentsel değişimin kent kimliği boyutu: Eskişehir örneği, Anadolu Üniversitesi Fen Bilimleri Enstitüsü Mimarlık Anabilim Dalı Yüksek Lisans Tezi, Eskişehir

Irmak MA (2008) Erzurum illi ve Yakın Çevresinin Flora Turizm PotansiyeliAçısından Değerlendirilmesi, Atatürk Üniversitesi Fen Bilimleri Enstitüsü, Doktora Tezi, Erzurum

Kiper T (2013) Kentsel ve Kırsal Alanların Planlanmasında Kimliğin Rolü, Türk Bilimsel Derlemeler Dergisi 6 (2): 73-77

Likert R (1932-1933) A Technique fort he Measurement of Attitudes, Archives of Psychology, Vol: 22, USA

Rescia AJ, Pons A, Lomba I, Esteban C, Dover JW (2008) Reformulating the social-ecological system in a cultural rural mountain landscape in the Picos de Europa region (northern Spain), Landscape and Urban Planning 88, 2333

Şahin S (1998) Bartın İlinin Beşeri Coğrafyası, Gazi Üniversitesi, Sosyal Bilimler Enstitüsü, Doktora Tezi, Ankara

Yılmaz B, Atik G (2006) Doğal Peyzaj Özelliklerinin Kırsal Yerleşimler Üzerindeki Etkileri - Bartın Örneği, ZKÜ Bartın Orman Fakültesi Dergisi, 8 (10)

Zaizhi Z (2000) Landscape changes in a rural area in China. Landscape and Urban Planning 47, 33-38 